\title{
Evaluation of three artificial diets in the culture of tropical edible frog Hoplobatrachus occipitalis (Günther, 1858) from tadpole stage to full metamorphosis
}

Moshood K. Mustapha ${ }^{*}$ and Shukurat O. Bello

\begin{abstract}
Background: The consumption of edible frogs caught mainly from the wild is on the rise and their population declining. A challenge to frog farming is the acceptability of artificial diets by frogs. Three artificial diets for the culture of a tropical edible frog Hoplobatrachus occipitalis from tadpole stage to full metamorphosis were evaluated. One hundred eighty Hoplobatrachus occipitalis tadpoles (average length and weight of $5.8 \mathrm{~cm} \pm 0.1$ and $1.90+\mathrm{g} \pm 0$. 1) were distributed into three experimental tanks with $60-\mathrm{L}$ water capacity each, renewed through a flow-through system. The tadpoles were fed twice daily at $10 \%$ of body mass for 112 days with duckweed, pawpaw leaf, and Coppens fish feed. Water quality parameters and proximate composition of the feeds were determined.

Results: Tadpoles fed with duckweed produced the highest percentage weight gained, specific growth rate, feed intake, and efficient food conversion, with mortality of 10\%, survival of $90 \%$, and metamorphosis rate of $100 \%$. This was followed by tadpoles fed with pawpaw leaf and those fed with fish feed. Mortality in these two groups was $15 \%$, survival $85 \%$, and metamorphosis rate $98 \%$. Water quality in the tanks was within the ranges optimal for the growth and survival of the tadpoles. The highest growth percentage recorded in tadpoles fed duckweed was due to the high percentage of crude protein in the feed, which was highly digestible and absorbable by the tadpoles. The duckweed suits the herbivorous feeding of the tadpoles which converted the feed to high biomass. A similar trend was observed for pawpaw leaf, and its growth performance as compared to duckweed was due to its low protein content. The lowest growth performance showed in tadpoles fed with Coppens feed in spite of its very high crude protein was due to the lower intake of the feed resulting in high FCR, ineffective absorbance, and utilization of the protein in the feed on the account of herbivorous feeding of the tadpoles. Size, pellet form, floating time, and odor of the feed were other factors responsible for the lower growth performance.
\end{abstract}

Conclusion: Duckweed is a good artificial diet for the breeding of Hoplobatrachus occipitalis due to its high protein content and acceptability by the species.

Keywords: Tadpole, Metamorphosis, Duckweed, Pawpaw leaf, Fish feed

\footnotetext{
*Correspondence: moonstapha@yahoo.com

Department of Zoology, University of Ilorin, PMB 1515, llorin 240003, Nigeria
} 


\section{Background}

The acceptance and consumption of edible frogs in sub-Saharan Africa is on the increase due to the increasing cost of traditional sources of animal protein such as beef, chicken, and fish. Most of these edible frogs are caught from the wild, and the overexploitation of the frogs along with habitat loss and degradation are among the greatest factors contributing to the declining population of these frogs. In order to save the species from further decline and total disappearance from water bodies and ensure the species ethical and economic values are preserved, captive breeding of edible frogs should be done. But, the aquaculture of the species is not as established as that of fish in many countries of sub-Saharan Africa.

In the nearest time, edible frog culture/farming will be a promising and profitable venture like fish farming and could overtake fish culture as a sustainable aquaculture species. This is due to the increasing demand of frog as an alternative source of animal protein, as well as its competitive edge in terms of production, affordability, and nutritive value as comparable to fish, beef, and chicken. Frog culture will also help in conserving the species as well as providing employment and income to people.

One of the challenges to successful breeding of frogs under artificial conditions in ponds or other aquacultureholding facilities is the use, affordability, and acceptability of artificial diets from tadpole stage to adult life. According to Helfrich, Neves, and Parkhurst (2001) and Alvarez and Nicieza (2002), the rate of growth of frog tadpole in the wild or in culture depends largely among other things on adequate and appropriate food. Apart from the food being adequate, it should also be acceptable and affordable with good feed conversion ratio to the frogs in both cultures at tadpole and adult stages with the tadpole stage being the critical stage for survival during metamorphosis.

Research on edible frog nutritional requirements is limited which poses a lot of challenges in improving the culture of these frogs from dietary perspective (Toledo, Suazo, \& Viana, 2014). The use of formulated diets is important to support the continuous and specific nutritional requirements of frogs (Tacon, 1990), while the provision of fresh natural diets could greatly help in the culture of frogs from tadpole stages.

The objectives of this study were to evaluate three artificial diets for the culture of tropical edible frog Hoplobatrachus occipitalis (Günther, 1858) from tadpole stage to full metamorphosis and compare the growth rate and metamorphosis of the tadpoles fed with the diets. This is with a view of adopting the best diet which is affordable and acceptable for the culture of the species for consumption, economic values, and subsequent release back to the wild for conservation.

\section{Methods}

\section{Experimental design}

One hundred eighty Hoplobatrachus occipitalis tadpoles with average length and weight of $5.8 \mathrm{~cm} \pm 0.1$ and $1.90 \mathrm{~g}$ \pm 0.1 , respectively, were obtained from a local fish farm pond in Ilorin, Nigeria, during their breeding season. The tadpoles were transported in three open tanks, each containing 60 tadpoles that were filled with $60 \mathrm{~L}$ of well-oxygenated water of the pond early in the morning at a temperature of $21^{\circ} \mathrm{C}$ to the Laboratory of the Department of Zoology, University of Ilorin, Ilorin, Nigeria. The frogs were acclimatized for 1 week before the commencement of the experiment.

In the laboratory, the tadpoles were distributed into three experimental tanks measuring $1 \times 1 \times 0.2 \mathrm{~m}$ (length, width, and depth). Each tank contained 20 tadpoles with 60 -L water capacity, well aerated, with water supply from borehole (ground water) and constantly renewed through a flow-through system. The tanks were covered with nets to prevent their escape and predation by birds during the rearing period.

\section{Experimental diets and feeding management}

Twenty-four hours to the commencement of the feeding trials, the tadpoles were starved to empty the gut. The tadpoles were fed with fresh duckweed (Lemma paucicostata) in tank 1, while in tank 2 and tank 3, they were fed with fresh chopped pawpaw leaf (Carica papaya) and 0.8-mm Coppens fish feed, respectively. The reasons for choosing these feeds were due to being the natural food of tadpoles, their availability locally, and being a cheap source of supplementary feed in aquaculture.

The proximate compositions of the feeds such as crude protein, crude fiber, total ash moisture, and nitrogen-free extract (NFE) were determined according to Association of Official Analytical Chemists (AOAC, 2010) in triplicates. The tadpoles were fed twice daily (8.00 a.m. and 6.00 p.m.) at $10 \%$ of their biomass for 16 weeks (112 days). The frogs were fed to about $95 \%$ satiation and cleaned daily which ensured that no residual of the feed were left in the tanks after feeding. Each of the tanks had three replicates. Water quality parameters such as dissolved oxygen, $\mathrm{pH}$, temperature, ammonia, conductivity, and total dissolved solids (TDS) were measured in the tanks using Hanna Multiparameter Bench Photometer for Laboratories Model HI 83200-02 and Hanna Portable $\mathrm{pH} / \mathrm{EC} / \mathrm{TDS} / \mathrm{Temp}$ combined waterproof tester. Triplicate water samples of the tanks were obtained and measured for all the chemical parameters, while $\mathrm{pH}$ and temperature, electrical conductivity, and total dissolved solids measurements were also measured in triplicates in situ. 


\section{Data collection}

Five tadpoles were randomly selected from each tank weekly for the measurement of body weight using a digital electronic weighing balance model FXi-WP. Survival and mortality of the tadpoles in the tanks were determined daily by counting the numbers of the live and dead tadpoles in the tanks.

The final body weight, survival, and mortality data were used to calculate the weight gained (WG), weight gain percentage (WG\%), specific growth rate (SGR), feed conversion ratio (FCR), survival/mortality rates and percentages, and the condition factor of the tadpoles in culture according to the following equations:

$$
\begin{aligned}
& \text { WG }(\mathrm{g})=\text { final tadpole weight }(\mathrm{FW})(\mathrm{g}) \\
& \quad-\text { initial tadpole weight }(\mathrm{IW})(\mathrm{g}), \\
& \text { WG }(\%)=100 \times[(\mathrm{FW}-\mathrm{IW}) / \mathrm{IW}] \\
& \text { SGR }=100 \times[(\mathrm{Ln} \mathrm{FW})-(\mathrm{Ln} \mathrm{IW})] / \text { experimental days, } \\
& \text { FCR }=\text { feed fed }(\mathrm{g}) / \text { weight gain }(\mathrm{g}), \\
& \text { Protein efficiency ratio }(\mathrm{PER})=\mathrm{WG}(\mathrm{g}) / \mathrm{PI}(\mathrm{g}), \\
& \text { Protein intake }(\mathrm{PI})=\text { feed intake }(\mathrm{FI}) \times \% \text { protein in feed, } \\
& \text { FI }=10 \% \text { of biomass of tadpole per day, } \\
& \text { Survival }(\mathrm{S})=\text { final tadpole count-initial tadpole count, } \\
& \text { Survival percentage }(\mathrm{S} \%) \\
& =(\text { final tadpole count } / \text { initial tadpole count }) \times 100 \\
& \text { Mortality }(\mathrm{M})=\text { number of dead tadpoles or final tadpole count }
\end{aligned}
$$

Mortality percentage $($ Mortality\% $)=($ number of dead tadpole/number of initial tadpole) $\times 100$

The rate of metamorphosis in the tadpoles was observed daily and deemed completed when the tadpoles in the tanks have their gills and tail disappear, mouth widen, and eyes bulge, while their lungs, fore limbs, and hind limbs have developed and the skin becomes smooth and porous.

\section{Statistical analysis}

Data were expressed as means and standard deviation $( \pm$ $\mathrm{SD})$. One-way ANOVA combined with least significant difference (LSD) and Duncan's multiple comparison tests were used to test significant differences between each treatment at $P<0.05$. Statistical Package for the Social Sciences (SPSS v.16) was used for the statistical analysis.

\section{Results}

Proximate composition of the feeds

The proximate composition of the feeds is presented in Table 1. Coppens fish feed showed the highest amount of crude protein (42\%), followed by duckweed (40.2\%), while pawpaw leaf had the lowest (32\%) among the three feeds used. Coppens also showed the highest composition of lipids among the three feeds. Significant difference $(P<0.05)$ was observed in the crude protein composition, crude lipids, total ash, and nitrogen-free extract (NFE) among the feeds.

\section{Growth and metamorphosis rate, performance, and feed utilization parameters}

The growth rate of the tadpoles cultured using three different artificial diets is presented in Fig. 1. The tadpoles fed with duckweed showed the highest growth rate, followed by those fed with pawpaw leaf, while tadpoles fed with Coppens fish feed showed the least growth rate after 16 weeks of feeding.

Table 2 shows the growth performance, feed utilization parameters, survival, mortality, and rate of metamorphosis of the tadpoles fed the three different feed types. Tadpoles fed with duckweed produced the highest final mean weight, mean weight gained, and percentage weight gained of $17.20 \pm 0.5 \mathrm{~g}, 15.30 \pm 0.4 \mathrm{~g}$, and 805. 26 $\pm 0.8 \%$, respectively. Similarly, tadpoles fed with duckweed showed the highest specific growth rate of $0.86 \pm$ 0.01 , feed intake of $21.28 \pm 0.12 \mathrm{~g}$, and protein efficiency ratio of $1.78 \pm 0.02 \mathrm{~g}$. The food conversion ratio in these tadpoles was $1.38 \pm 0.02 \mathrm{~g}$, while mortality recorded in the tank was $2(10 \%)$, survival was $18(90 \%)$, and rate of metamorphosis was $100 \%$. Following tadpoles fed with duckweed, in terms of growth performance, feed utilization parameters, survival, mortality, and rate of metamorphosis were tadpoles fed with pawpaw leaf which showed a final mean weight, mean weight gained, and percentage weight gained of $16.60 \pm 0.5 \mathrm{~g}, 14.70 \pm$ $0.4 \mathrm{~g}$, and 773. $68 \pm 0.8 \%$, respectively. The specific

Table 1 Proximate composition of the different feeds used in the culture of Hoplobatrachus occipitalis from tadpole stage to full metamorphosis

\begin{tabular}{llll}
\hline Proximate composition \% & Duckweed & Pawpaw leaf & Coppens fish feed \\
\hline Crude protein & $40.2^{\mathrm{a}}$ & $33.4^{\mathrm{b}}$ & $42.0^{\mathrm{c}}$ \\
Crude lipids & $9.2^{\mathrm{a}}$ & $6.2^{\mathrm{b}}$ & $12.0^{\mathrm{c}}$ \\
Crude fiber & $5.7^{\mathrm{a}}$ & $5.8^{\mathrm{a}}$ & $1.9^{\mathrm{b}}$ \\
Total ash & $15.6^{\mathrm{a}}$ & $8.4^{\mathrm{b}}$ & $9.5^{\mathrm{c}}$ \\
Moisture & $83.0^{\mathrm{a}}$ & $10.2^{\mathrm{b}}$ & $10.0^{\mathrm{b}}$ \\
NFE & $29.3^{\mathrm{a}}$ & $46.2^{\mathrm{b}}$ & $34.6^{\mathrm{c}}$ \\
\hline
\end{tabular}

NFE nitrogen-free extract $=100-$ (crude protein $\%+$ crude lipids $\%+$ crude fiber $\%+$ total ash \%)

Mean values in the same row with different superscript letters are significantly different $(p<0.05)$ 


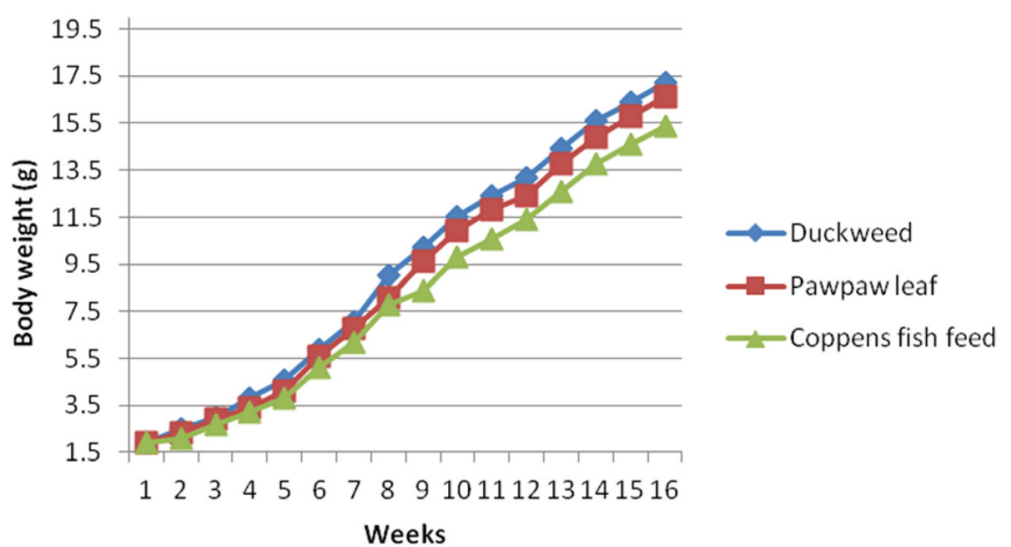

Fig. 1 Growth rate of (Hoplobatrachus occipitalis) tadpoles fed three different types of feed (duckweed, pawpaw leaf, and Coppens fish feed) from tadpole stage to full metamorphosis

growth rate in this group was $0.84 \pm 0.01$, feed intake $20.62 \pm 0.12 \mathrm{~g}$, and protein efficiency ratio $1.76 \pm 0.02 \mathrm{~g}$, while the food conversion ratio was $1.40 \pm 0.02 \mathrm{~g}$. The mortality recorded in the tank was $3(15 \%)$, survival 17 $(85 \%)$, and rate of metamorphosis was $98 \%$ with only one tadpole not fully metamorphosed at the end of the 16 weeks feeding trial. Among the three treatments, tadpoles fed with Coppens fish feed produced the lowest final mean weight, mean weight gained, and percentage weight gained of $15.50 \pm 0.5 \mathrm{~g}, 13.60 \pm 0.4 \mathrm{~g}$, and 715.79 $\pm 0.8 \%$, respectively. The specific growth rate of the tadpoles in this group was $0.81 \pm 0.01$, feed intake of 19.46 $\pm 0.12 \mathrm{~g}$, and protein efficiency ratio of $1.67 \pm 0.02 \mathrm{~g}$, food conversion ratio $1.42 \pm 0.02 \mathrm{~g}$, while mortality recorded in the tank was 3 (15\%), survival 17 (85\%), and rate of metamorphosis was $98 \%$ with only one tadpole not fully metamorphosed at the end of the 16-week feeding trial.

There were significant differences in final mean weight, mean weight gained, percentage weight gained, specific growth rate, feed intake, FCR, and PER among the three feed types. No significant differences $(P>0.05)$ were found in the mortality, mortality percentage, survival, survival percentage, and metamorphosis rate among the tadpoles in the three tanks.

\section{Water quality}

The range of water quality parameters in the three tanks is presented in Tables 3, 4, and 5, while the overall mean values of water quality parameters in the three tanks are shown in Table 6.

Table 2 Tadpole growth performance, survival, mortality, feed utilization, and metamorphosis rate fed three different types of feed (duckweed, pawpaw leaf, and Coppens fish feed)

\begin{tabular}{llll}
\hline Parameter & Duckweed & Pawpaw leaf & Coppens fish feed \\
\hline Initial mean weight (g) & 1.90 & 1.90 & 1.90 \\
Final mean weight (g) & 17.20 & 16.60 & 15.50 \\
Mean weight gained (g) & 15.30 & 14.70 & 13.60 \\
Percentage weight gained (\%) & 805.26 & 773.68 & 715.79 \\
Specific growth rate & 0.86 & 0.84 & 0.81 \\
Feed intake & 21.28 & 20.62 & 19.46 \\
Protein intake & 5.49 & 4.38 & 5.1 \\
Feed conversion ratio & 1.38 & 1.40 & 1.42 \\
Protein efficiency ratio & 1.78 & 1.76 & 1.67 \\
Mortality & 2 & 3 & 3 \\
Mortality percentage (\%) & 10 & 15 & 15 \\
Survival & 18 & 17 & 17 \\
Survival percentage (\%) & 90 & 85 & 85 \\
Percentage rate of metamorphosis (\%) & 100 & 98 & 98 \\
\hline
\end{tabular}


Table 3 Mean weekly variations in water quality parameters in tank 1 (duckweed)

\begin{tabular}{|c|c|c|c|c|c|c|}
\hline Week & $\begin{array}{l}\text { Temp } \\
\left({ }^{\circ} \mathrm{C}\right)\end{array}$ & $\mathrm{pH}$ & $\begin{array}{l}\mathrm{EC} \\
\mu \mathrm{S} / \mathrm{cm}\end{array}$ & $\begin{array}{l}\text { TDS } \\
\mathrm{mg} \mathrm{L}^{-1}\end{array}$ & $\begin{array}{l}\mathrm{DO} \\
\mathrm{mg} \mathrm{L}^{-1}\end{array}$ & $\begin{array}{l}\mathrm{NH}_{3} \\
\mathrm{mg} \mathrm{L}^{-1}\end{array}$ \\
\hline 1 & $27.1 \pm 0.1$ & $6.8 \pm 0.1$ & $240 \pm 0.1$ & $161 \pm 0.1$ & $6.2 \pm 0.1$ & $0.11 \pm 0.01$ \\
\hline 2 & $27.1 \pm 0.1$ & $6.8 \pm 0.1$ & $240 \pm 0.1$ & $161 \pm 0.1$ & $6.2 \pm 0.1$ & $0.11 \pm 0.01$ \\
\hline 3 & $27.0 \pm 0.1$ & $6.8 \pm 0.1$ & $244 \pm 0.1$ & $163 \pm 0.1$ & $6.3 \pm 0.1$ & $0.12 \pm 0.01$ \\
\hline 4 & $27.0 \pm 0.1$ & $6.9 \pm 0.1$ & $248 \pm 0.1$ & $166 \pm 0.1$ & $6.4 \pm 0.1$ & $0.14 \pm 0.01$ \\
\hline 5 & $26.8 \pm 0.1$ & $6.9 \pm 0.1$ & $250 \pm 0.1$ & $168 \pm 0.1$ & $6.4 \pm 0.1$ & $0.14 \pm 0.01$ \\
\hline 6 & $26.8 \pm 0.1$ & $6.9 \pm 0.1$ & $252 \pm 0.1$ & $169 \pm 0.1$ & $6.5 \pm 0.1$ & $0.16 \pm 0.01$ \\
\hline 7 & $26.7 \pm 0.1$ & $6.9 \pm 0.1$ & $255 \pm 0.1$ & $171 \pm 0.1$ & $6.5 \pm 0.1$ & $0.16 \pm 0.01$ \\
\hline 8 & $26.6 \pm 0.1$ & $7.0 \pm 0.1$ & $260 \pm 0.1$ & $174 \pm 0.1$ & $6.6 \pm 0.1$ & $0.18 \pm 0.01$ \\
\hline 9 & $26.6 \pm 0.1$ & $7.0 \pm 0.1$ & $260 \pm 0.1$ & $174 \pm 0.1$ & $6.6 \pm 0.1$ & $0.18 \pm 0.01$ \\
\hline 10 & $26.2 \pm 0.1$ & $7.1 \pm 0.1$ & $266 \pm 0.1$ & $178 \pm 0.1$ & $6.6 \pm 0.1$ & $0.18 \pm 0.01$ \\
\hline 11 & $25.9 \pm 0.1$ & $7.1 \pm 0.1$ & $268 \pm 0.1$ & $180 \pm 0.1$ & $6.8 \pm 0.1$ & $0.18 \pm 0.01$ \\
\hline 12 & $25.8 \pm 0.1$ & $7.2 \pm 0.1$ & $272 \pm 0.1$ & $182 \pm 0.1$ & $6.8 \pm 0.1$ & $0.19 \pm 0.01$ \\
\hline 13 & $25.0 \pm 0.1$ & $7.2 \pm 0.1$ & $275 \pm 0.1$ & $184 \pm 0.1$ & $6.9 \pm 0.1$ & $0.20 \pm 0.01$ \\
\hline 14 & $24.6 \pm 0.1$ & $7.2 \pm 0.1$ & $278 \pm 0.1$ & $186 \pm 0.1$ & $6.9 \pm 0.1$ & $0.20 \pm 0.01$ \\
\hline 15 & $24.4 \pm 0.1$ & $7.2 \pm 0.1$ & $278 \pm 0.1$ & $186 \pm 0.1$ & $6.9 \pm 0.1$ & $0.20 \pm 0.01$ \\
\hline 16 & $24.2 \pm 0.1$ & $7.2 \pm 0.1$ & $280 \pm 0.1$ & $188 \pm 0.1$ & $6.9 \pm 0.1$ & $0.20 \pm 0.01$ \\
\hline Overall Total mean & $26.11 \pm 0.1$ & $7.01 \pm 0.1$ & $260.25 \pm 0.1$ & $174.38 \pm 0.1$ & $6.59 \pm 0.1$ & $0.16 \pm 0.01$ \\
\hline
\end{tabular}

The mean weekly results of the water quality variables in each tank are presented in Tables 1, 2, and 3 . The overall mean of all the water quality parameters for the culture of tropical edible frog (Rana esculenta) from tadpole stage to full metamorphosis is shown in Table 4.
Temperature in the tanks ranged between 24.1 and $27.2{ }^{\circ} \mathrm{C}$ with the lowest and highest recorded in weeks 1 and 16 respectively. There were no significant differences $(P>0.05)$ in temperature variations among the three tanks; however, there were significant differences $(P<0.05)$ in the temporal variations in the tanks. The

Table 4 Mean weekly variations in water quality parameters in tank 2 (pawpaw leaf)

\begin{tabular}{|c|c|c|c|c|c|c|}
\hline Week & $\begin{array}{l}\text { Temp } \\
\left({ }^{\circ} \mathrm{C}\right)\end{array}$ & $\mathrm{pH}$ & $\begin{array}{l}E C \\
\mu S / c m\end{array}$ & $\begin{array}{l}\text { TDS } \\
\mathrm{mg} \mathrm{L}^{-1}\end{array}$ & $\begin{array}{l}\mathrm{DO} \\
\mathrm{mg} \mathrm{L}^{-1}\end{array}$ & $\begin{array}{l}\mathrm{NH}_{3} \\
\mathrm{mg} \mathrm{L}^{-1}\end{array}$ \\
\hline 1 & $27.1 \pm 0.1$ & $6.8 \pm 0.1$ & $240 \pm 0.1$ & $161 \pm 0.1$ & $6.2 \pm 0.1$ & $0.10 \pm 0.01$ \\
\hline 2 & $27.1 \pm 0.1$ & $6.8 \pm 0.1$ & $241 \pm 0.1$ & $161 \pm 0.1$ & $6.3 \pm 0.1$ & $0.10 \pm 0.01$ \\
\hline 3 & $27.0 \pm 0.1$ & $6.8 \pm 0.1$ & $242 \pm 0.1$ & $162 \pm 0.1$ & $6.3 \pm 0.1$ & $0.10 \pm 0.01$ \\
\hline 4 & $26.9 \pm 0.1$ & $6.9 \pm 0.1$ & $244 \pm 0.1$ & $164 \pm 0.1$ & $6.4 \pm 0.1$ & $0.11 \pm 0.01$ \\
\hline 5 & $26.9 \pm 0.1$ & $6.9 \pm 0.1$ & $248 \pm 0.1$ & $166 \pm 0.1$ & $6.4 \pm 0.1$ & $0.11 \pm 0.01$ \\
\hline 6 & $26.8 \pm 0.1$ & $6.9 \pm 0.1$ & $250 \pm 0.1$ & $168 \pm 0.1$ & $6.4 \pm 0.1$ & $0.12 \pm 0.01$ \\
\hline 7 & $26.7 \pm 0.1$ & $6.9 \pm 0.1$ & $254 \pm 0.1$ & $170 \pm 0.1$ & $6.5 \pm 0.1$ & $0.14 \pm 0.01$ \\
\hline 8 & $26.5 \pm 0.1$ & $6.9 \pm 0.1$ & $258 \pm 0.1$ & $173 \pm 0.1$ & $6.5 \pm 0.1$ & $0.15 \pm 0.01$ \\
\hline 9 & $26.2 \pm 0.1$ & $7.0 \pm 0.1$ & $260 \pm 0.1$ & $174 \pm 0.1$ & $6.5 \pm 0.1$ & $0.16 \pm 0.01$ \\
\hline 10 & $26.0 \pm 0.1$ & $7.0 \pm 0.1$ & $262 \pm 0.1$ & $176 \pm 0.1$ & $6.6 \pm 0.1$ & $0.16 \pm 0.01$ \\
\hline 11 & $25.8 \pm 0.1$ & $7.0 \pm 0.1$ & $266 \pm 0.1$ & $178 \pm 0.1$ & $6.6 \pm 0.1$ & $0.18 \pm 0.01$ \\
\hline 12 & $25.6 \pm 0.1$ & $7.0 \pm 0.1$ & $270 \pm 0.1$ & $181 \pm 0.1$ & $6.7 \pm 0.1$ & $0.18 \pm 0.01$ \\
\hline 13 & $24.7 \pm 0.1$ & $7.1 \pm 0.1$ & $272 \pm 0.1$ & $182 \pm 0.1$ & $6.8 \pm 0.1$ & $0.20 \pm 0.01$ \\
\hline 14 & $25.6 \pm 0.1$ & $7.2 \pm 0.1$ & $275 \pm 0.1$ & $184 \pm 0.1$ & $6.8 \pm 0.1$ & $0.20 \pm 0.01$ \\
\hline 15 & $24.2 \pm 0.1$ & $7.2 \pm 0.1$ & $278 \pm 0.1$ & $186 \pm 0.1$ & $6.9 \pm 0.1$ & $0.20 \pm 0.01$ \\
\hline 16 & 24.1 & 7.2 & 278 & 186 & $6.9 \pm 0.1$ & $0.22 \pm 0.01$ \\
\hline Overall total mean & $26.0 \pm 0.15$ & $6.97 \pm 0.1$ & $258.63 \pm 0.1$ & $173.25 \pm 0.1$ & $6.60 \pm 0.1$ & $0.15 \pm 0.01$ \\
\hline
\end{tabular}


Table 5 Mean weekly variations in water quality parameters in tank 3 (Coppens fish feed)

\begin{tabular}{lllllll}
\hline Week & $\begin{array}{l}\text { Temp } \\
\left({ }^{\circ} \mathrm{C}\right)\end{array}$ & $\mathrm{pH}$ & $\mathrm{EC}$ & $\mathrm{TS} / \mathrm{cm}$ & $\mathrm{mO}$ & $\begin{array}{l}\mathrm{DO} \\
\mathrm{mg} \mathrm{L}^{-1}\end{array}$ \\
\hline 1 & $27.2 \pm 0.1$ & $6.8 \pm 0.1$ & $240 \pm 0.1$ & $161 \pm 0.1$ & $6.2 \pm 0.1$ & $\begin{array}{l}\mathrm{NH}_{3} \\
\mathrm{mg} \mathrm{L}^{-1}\end{array}$ \\
2 & $27.1 \pm 0.1$ & $6.8 \pm 0.1$ & $244 \pm 0.1$ & $164 \pm 0.1$ & $6.3 \pm 0.1$ & $0.11 \pm 0.01$ \\
3 & $27.0 \pm 0.1$ & $6.9 \pm 0.1$ & $249 \pm 0.1$ & $164 \pm 0.1$ & $6.3 \pm 0.1$ & $0.12 \pm 0.01$ \\
4 & $27.0 \pm 0.1$ & $6.9 \pm 0.1$ & $246 \pm 0.1$ & $165 \pm 0.1$ & $6.3 \pm 0.1$ & $0.12 \pm 0.01$ \\
5 & $26.9 \pm 0.1$ & $6.9 \pm 0.1$ & $246 \pm 0.1$ & $165 \pm 0.1$ & $6.4 \pm 0.1$ & $0.12 \pm 0.01$ \\
6 & $26.9 \pm 0.1$ & $6.9 \pm 0.1$ & $250 \pm 0.1$ & $168 \pm 0.1$ & $6.4 \pm 0.1$ & $0.13 \pm 0.01$ \\
7 & $26.8 \pm 0.1$ & $7.0 \pm 0.1$ & $254 \pm 0.1$ & $170 \pm 0.1$ & $6.4 \pm 0.1$ & $0.14 \pm 0.01$ \\
8 & $26.6 \pm 0.1$ & $7.0 \pm 0.1$ & $256 \pm 0.1$ & $172 \pm 0.1$ & $6.5 \pm 0.1$ & $0.16 \pm 0.01$ \\
9 & $26.2 \pm 0.1$ & $7.0 \pm 0.1$ & $260 \pm 0.1$ & $174 \pm 0.1$ & $6.5 \pm 0.1$ & $0.16 \pm 0.01$ \\
10 & $26.0 \pm 0.1$ & $7.1 \pm 0.1$ & $264 \pm 0.1$ & $177 \pm 0.1$ & $6.5 \pm 0.1$ & $0.18 \pm 0.01$ \\
11 & $25.8 \pm 0.1$ & $7.1 \pm 0.1$ & $268 \pm 0.1$ & $180 \pm 0.1$ & $6.6 \pm 0.1$ & $0.18 \pm 0.01$ \\
12 & $25.2 \pm 0.1$ & $7.1 \pm 0.1$ & $272 \pm 0.1$ & $181 \pm 0.1$ & $6.7 \pm 0.1$ & $0.19 \pm 0.01$ \\
13 & $24.8 \pm 0.1$ & $7.1 \pm 0.1$ & $278 \pm 0.1$ & $186 \pm 0.1$ & $6.8 \pm 0.1$ & $0.20 \pm 0.01$ \\
14 & $24.5 \pm 0.1$ & $7.2 \pm 0.1$ & $278 \pm 0.1$ & $186 \pm 0.1$ & $6.8 \pm 0.1$ & $0.20 \pm 0.01$ \\
15 & $24.2 \pm 0.1$ & $7.2 \pm 0.1$ & $280 \pm 0.1$ & $188 \pm 0.1$ & $6.9 \pm 0.1$ & $0.20 \pm 0.01$ \\
16 & $24.1 \pm 0.1$ & $7.2 \pm 0.1$ & $280 \pm 0.1$ & $188 \pm 0.1$ & $6.9 \pm 0.1$ & $0.20 \pm 0.01$ \\
Overall total mean & $26.01 \pm 0.1$ & $7.01 \pm 0.1$ & $260.05 \pm 0.1$ & $174.20 \pm 0.1$ & $6.59 \pm 0.1$ & $0.16 \pm 0.01$ \\
\hline & & & & &
\end{tabular}

overall mean of temperature measurements in the three tanks was $26.05{ }^{\circ} \mathrm{C}$.

$\mathrm{pH}$ variations were from the lowest of 6.8 recorded in the first week in all the tanks to the highest of 7.2 recorded in week 16 in all the tanks. There was no significant difference $(P>0.05)$ in the spatial and temporal variations in the $\mathrm{pH}$ in the tanks. The overall mean $\mathrm{pH}$ recorded in the tanks was 6.99 .

Electrical conductivity (EC) varied between a minimum of $240 \mu \mathrm{S} / \mathrm{cm}$ recorded in week 1 in all the tanks and a maximum of $280 \mu \mathrm{S} / \mathrm{cm}$ recorded in week 16 in tanks 1 and 3 , respectively. There were no significant differences $(P>0.05)$ in the variations of electrical conductivity in the three tanks, but there were significant differences $(P<0.05)$ in weekly variations in the tanks. The overall mean of the electrical conductivity measurements in the three tanks was $259.64 \mu \mathrm{S} / \mathrm{cm}$.

Table 6 Overall mean values of water quality parameters in the three tanks for the culture of tropical edible frog

(Hoplobatrachus occipitalis) from tadpole stage to full metamorphosis

\begin{tabular}{ll}
\hline Water quality parameters & Overall mean value \\
\hline Temperature $\left({ }^{\circ} \mathrm{C}\right)$ & $26.05 \pm 0.1$ \\
$\mathrm{pH}$ & $6.99 \pm 0.1$ \\
Electrical conductivity (EC) $(\mu \mathrm{S} / \mathrm{cm})$ & $259.64 \pm 0.1$ \\
Total dissolved solids (TDS) $\left(\mathrm{mg} \mathrm{L}^{-1}\right)$ & $173.94 \pm 0.1$ \\
Dissolved oxygen (DO) $\left(\mathrm{mg} \mathrm{L}^{-1}\right)$ & $6.59 \pm 0.1$ \\
Total ammonia $\left(\mathrm{mg} \mathrm{L}^{-1}\right)$ & $0.16 \pm 0.01$ \\
\hline
\end{tabular}

Total dissolved solids (TDS) varied between a minimum of $161 \mathrm{mg} / \mathrm{L}$ recorded in week 1 in all the tanks and a maximum of $188 \mathrm{mg} / \mathrm{L}$ recorded in week 16 in tanks 1 and 3 , respectively. There were no significant differences $(P>0.05)$ in the variations of TDS in the three tanks, but there were significant differences $(P<$ $0.05)$ in weekly variations in TDS among the tanks.

The highest dissolved oxygen concentration of $6.9 \mathrm{mg} /$ $\mathrm{L}$ was recorded in all the three tanks in week 16, while the lowest of $6.2 \mathrm{mg} / \mathrm{L}$ was recorded in week 1 also in all the tanks. There was no significant difference $(P>$ $0.05)$ in the concentration of dissolved oxygen among the tanks and in the weeks. The overall mean of dissolved oxygen concentration in the tanks was $6.59 \mathrm{mg} / \mathrm{L}$.

Ammonia varied between the lowest concentration of $0.10 \mathrm{mg} / \mathrm{L}$ found in tank 1 in week 1 and highest concentration of $0.22 \mathrm{mg} / \mathrm{L}$ recorded in week 16 also in tank 3 . There was no significant difference $(P>0.05)$ in the concentration of ammonia among the tanks and in the weeks. The overall mean ammonia concentration in the tanks was $0.16 \mathrm{mg} / \mathrm{L}$.

\section{Discussion}

The success of frog breeding either for food, economic value, or conservation reasons starts from adequate and acceptable feed and feeding of the tadpoles. Growth and development (metamorphosis) of tadpoles have been known to be influenced among other things by the quality and quantity of food available to them (Alvarez \& Nicieza, 2002). The growth performance, feed utilization 
parameters, survival, mortality, and rate of metamorphosis of the tadpoles in this research was linked to the proximal composition of the different feeds as well as the optimal water quality condition in the tanks in which the frogs were bred.

The highest growth percentage recorded in tadpoles fed with duckweed was due to high percentage of crude protein, crude lipids, and total ash in the feed which were of high nutritive value to the tadpoles. Akasay (1994) had earlier reported that duckweed is a potential source of natural feed for frog breeding. The duckweed suits the herbivorous feeding of the tadpoles which converted the feed to high biomass as recorded in the final mean weight, weight gained, weight gained percentage, and SGR. The low FCR recorded for the feed was due to high digestibility of the feed which resulted in the highest weight gained among the three feeds. The highest PER was due to the high amount of protein in the feed which was readily absorbable by the tadpoles. Latsamy and Preston (2008) observed growth rates of tadpoles were higher when frogs were fed with duckweed. This is a result of the high intake of crude protein in the duckweed. According to Carmona-Osalde, Olvera-Novoa, Rodriguez-Serna, and Flores-Nava (1996), dietary protein content affects the growth rate of tadpoles and the metamorphic climax can only be achieved when the tadpole fulfills its nutritional requirements, permitting them to transform into a new and completely different animal. This probably explains the $100 \%$ metamorphosis rate recorded among the tadpoles. Likewise, the $90 \%$ survival and $10 \%$ mortality rates in this treatment group could be explained by the adequate and high nutritive composition of the duckweed. Pawpaw leaf was palatable to tadpoles of Hoplobatrachus occipitalis which they digested efficiently. This was due to their herbivorous feeding habit. The lower crude protein percentage in the pawpaw leaf as compared to duckweed was responsible for the significant differences $(P<0.05)$ in the final mean weight, weight gained, weight gained percentage, and SGR when compared with duckweed. Pawpaw leaf is however an excellent natural diet for tadpoles. Olaniyi and Salau (2013) had reported that inclusion of $20 \%$ pawpaw leaf in fish meal significantly improved the growth of African catfish Clarias gariepinus.

Although Coppens fish feed contained the highest crude protein among the three experimental diets, the final mean weight, mean weight gained, percentage weight gained, and SGR were significantly lower than those of duckweed and pawpaw leaf. This was due to the lower intake of the feed resulting in high FCR as compared to the other two diets. The lower growth performance could also be attributed to the ineffective absorbance and utilization of the protein in the feed on account of the long, coiled intestine and herbivorous feeding of the tadpoles. The size, pellet form, floating time, odor, and high crude protein content of the
Coppens fish feed could also be factors responsible for the lower growth performance. Mansano, De Stéfani, Pereira, Nascimento, and Macente (2014) reported that bullfrog tadpoles under captivity showed a lower growth rate when fed with commercial diets, while Rodriquez-Serna, FloresNava, Olvera-Nova, and Carmona-Osalde (1996) observed that growth rates of frogs raised with pelleted feed were considerably less compared to natural feeds. Sretarugsa, Luangborisut, Kruatrachue, and Upathan (1997) explained that high dietary protein above $40 \%$ is counterproductive in tadpole larva growth and development, while Mandelli et al. (1985) showed that pelleted feed of $0.21 \mathrm{~mm}$ in diameter was most suitable for tadpole rearing. The slight low metamorphosis rate (98\%), survival (85\%), and high mortality $(15 \%)$ rates though not significantly different $(P<$ 0.05 ) from the duckweed and pawpaw leaf could be as a result of the inability of the tadpoles to utilize the feed completely which prevented them from storing enough energy as well as the contamination of the water when the feed deteriorate. The use of fish feed in frog breeding at the tadpole stage could be expensive and should only be used if there are no natural vegetative matter such as duckweed, pawpaw, and lettuce.

It should, however, be noted that proteins alone does not determine the growth performance of tadpoles under culture. Other nutrients such as lipids, carbohydrates, and micro and macro nutrients also contribute to the growth and larva development (metamorphosis) of the tadpoles. Thus, feed that will be used in culture of frogs from tadpole stage should contain these nutrients in the right proportion. Browne (2009) did a comprehensive review on the diet and nutrition of amphibians.

The water quality values recorded in this work were within the ranges considered to be optimal for the rearing of the tadpole of Hoplobatrachus occipitalis. For example, temperature ranges is between 24 and $28^{\circ} \mathrm{C}$, with the average being $26^{\circ} \mathrm{C}$. This temperature ranges has been reported by Mercante, Vaz-dos-Santos, Moraes, Pereira, and Lombardi (2014) as ideal for the growth of frog tadpoles in ponds. This temperature which is ideal should be maintained during culture especially in tropical climate since the growth of frogs is related to temperature (Flores-Nava, 2000). The $\mathrm{pH}$ ranges is from slight acidity to slight alkalinity, with a range of 6.8 to 7.2 and an overall average of 6.9 (slight acidity). Castro and Pinto (2000) reported $\mathrm{pH}$ values around 7.33, towards the alkaline range, and Ferreira (2003) recommended mild acidity, while Sipaúba-Tavares, Morais, and De Stéfani (2008) suggested a pH range between 6.5 and 7.0 as ideal for frog culture. The electrical conductivity and total dissolved solids which were positively correlated were in the ranges optimal for Hoplobatrachus occipitalis production in tropical artificial conditions. Klaver, Peterson, and Patla (2013) reported that high conductivity water supports frog breeding. Borges, Amaral, and 
De Stéfani (2012) recommended a conductivity value of $249 \mu \mathrm{S} / \mathrm{cm}$ for bullfrog culture. Mean conductivity of $259.64 \mu \mathrm{S} / \mathrm{cm}$ and mean TDS of $173.94 \mathrm{mg} / \mathrm{L}$ will be the most ideal water quality values for the culture of tropical edible frog Hoplobatrachus occipitalis.

The range of ammonia recorded in the tanks was lower than that reported by Mercante et al. (2014) and Borges et al. (2014), but was in the range recommended by Ferreira (2003). Thus, a range of $0.1-0.25 \mathrm{mg} / \mathrm{L}$ of ammonia in tanks is an ideal water quality value for successful culture of Hoplobatrachus occipitalis.

Metamorphosizing tadpoles require enough dissolved oxygen which they extract from the water through their gills. It is therefore imperative that water for the breeding of frogs should contain high dissolved oxygen. Dissolved oxygen values recorded in this work could be described as optimal for the culture of edible tropical frog Hoplobatrachus occipitalis. These values were also similar to the values recorded by Hailey, Sookoo, Mohammed, and Khan (2006) and Borges et al. (2014) for the growth of frog tadpoles.

Duckweed has been shown to provide the highest growth performance, survival and metamorphosis rates, and very low mortality rate among the three experimental diets in Hoplobatrachus occipitalis tadpole culture. Fish feeds such as Coppens could be used for the breeding of the tadpole, but only if there are no vegetative matters around considering the fact tadpoles are herbivorous in their feeding habit. Also, when using fish feed, inclusion of plant materials and vitamin $\mathrm{C}$ in the feed will aid the utilization, absorbance, and digestibility of the feed.

\section{Conclusions}

Duckweed is a good artificial diet for the breeding of Hoplobatrachus occipitalis due to its high protein content, affordability, and acceptability by the species. The use of artificial diets in the culture of the species would not only save the species from further decline and total disappearance from water bodies but will also ensure that the species ethical values are preserved and its economic and nutritional values are not lost. Conservation of the species is desirable as it will preserve the genetic variability of the species and improve the eco-biodiversity of habitat where they are found.

With all the experimental diets proven to be very good for the tadpole's growth, researches should now focus on mixing the diets in order to see the performance of the mixed diets over each of the experimental diets.

For conservation purposes, wild collection of edible frogs for consumption should be discouraged. But, this might not be possible especially in developing countries of sub-Saharan Africa, due to the increasing cost of traditional sources of animal protein such as beef, chicken, and fish. To prevent the declining population and total extinction of edible frogs as well as increasing its production, captive breeding with the use of artificial diets will be desirable for the species.

\section{Abbreviations \\ FCR: Feed conversion ratio; Fl: Feed intake; FW: Final tadpole weight: IW: Initial tadpole weight; M: Mortality; Mortality\%: Mortality percentage; NFE: Nitrogen-free extract; PER: Protein efficiency ratio; pH/EC/TDS/Temp: $\mathrm{pH}$, electrical conductivity, total dissolved solids, temperature; PI: Protein intake; S: Survival; S\%: Survival percentage; SGR: Specific growth rate; TDS: Total dissolved solids; WG: Weight gain; WG\%: Weight gain percentage}

\section{Acknowledgements}

The authors will like acknowledge the fish farm workers who provided them with Hoplobatrachus occipitalis tadpoles free of charge.

Funding

This study was not funded by any institution, agency, or entity.

\section{Availability of data and materials}

The datasets generated and analyzed during the current study are available from the corresponding author on reasonable request.

\section{Authors' contributions}

MKM suggested the study and participated in its design and coordination. SOB carried out the feeding trial, sample collection, and analysis. MKM carried out the statistical data analysis and interpreted the results. MKM prepared the first draft of the manuscript. Both authors read and approved the final manuscript

\section{Ethics approval \\ All applicable international, national, and institutional guidelines for the care and use of animals were followed. All procedures performed in this study involving the frog Hoplobatrachus occipitalis were in accordance with the ethical standards of the University of Ilorin, llorin, Nigeria, where the study was conducted and who granted the ethical approval for the conduct of the research.}

Consent for publication

Not applicable

\section{Competing interests}

The authors declare that they have no competing interests.

\section{Publisher's Note}

Springer Nature remains neutral with regard to jurisdictional claims in published maps and institutional affiliations.

Received: 29 May 2018 Accepted: 9 October 2018

Published online: 23 October 2018

\section{References}

Akasay, N. (1994). Frog culture for commercial trade. Thailand: Cooperative frog culture.

Alvarez, D., \& Nicieza, A. G. (2002). Effects of temperature and food quality on anuran larval growth and metamorphosis. Functional Ecology, 16, 640-648.

Association of Official Analytical Chemists (AOAC) (2010). Official methods of analysis. 18th edition, revision 3. Washington DC: Association of Official Analytical Chemists.

Borges, F. F., Amaral, L. A., \& De Stéfani, M. V. (2012). Characterization of effluents from bullfrog (Lithobates catesbeianus, Shaw, 1802) grow-out ponds. Acta Limnologica Brasiliensia, 24, 160-166.

Borges, F. F., De Stéfani, M. V., \& Amaral, L. A. (2014). Quality of the effluents of bullfrog tadpole ponds. Boletimdo Instituto de Pesca, 40(3), 409-417.

Browne, R. K. (2009). Amphibian diet and nutrition. MN, USA: AArk Science and Research publication.

Carmona-Osalde, C., Olvera-Novoa, M. A., Rodriguez-Serna, M., \& Flores-Nava, A. (1996). Estimation of the protein requirement for bullfrog (Rana catesbeiana) tadpoles, and its effect on metamorphosis ratio. Aquaculture, 141(1-4), 223-231.

Castro, J. C., \& Pinto, A. T. (2000). Qualidade da água em tanques de girinos de ră-touro, Rana catesbeiana Shaw, 1802, cultivados em diferentes densidades de estocagem. Revista Brasileira de Zootecnia, 29, 1903-1911. 
Ferreira, C. M. (2003). A importância da água e sua utilização em ranários comerciais. Panorama da Aquicultura, 13, 15-17.

Flores-Nava, A. (2000). Bullfrog farming. Comparison of inundated and semi dry ongoing methods. Global Aquaculture Alliance, 1, 52-54.

Hailey, A., Sookoo, N., Mohammed, A., \& Khan, A. (2006). Factors affecting tadpole growth: Development of a rearing system for the Neotropical Leptodactylid Physalaemus pustulosus for ecotoxicological studies. Applied Herpetology, 3(2), $111-128$.

Helfrich, L. A., Neves, R. J., \& Parkhurst, J. (2001). Commercial frog farming. USA: Virginia Cooperative Extension. Virginia State University.

Klaver, R. W., Peterson, C. R., \& Patla, D. A. (2013). Influence of water conductivity on amphibian occupancy in the greater yellow stone ecosystem. Western North American Naturalist, 73, 184-197.

Latsamy, P., \& Preston, T. R. (2008). Fly larvae, earthworms and duckweed as feeds for frogs in an integrated farming system. Livestock Research for Rural Development, 20, 1-10.

Mandelli, J., Justo, C. L., Penteado, L. A., Fontanello, D., Arruda-Soares, H., \& Campos, B. E. S. (1985). Effect of particle size of the feed on weight gain of intensively reared tadpoles of Rana catesbeiana (Shaw 1802). Boletin del Instituto de Pesca, 12, 61-66.

Mansano, C. F. M., De Stéfani, M. V., Pereira, M. M., Nascimento, T. S. R., \& Macente, B. I. (2014). Morphometric growth characteristics and body composition of bullfrog tadpoles in captivity. Ciências Agrárias, 35(5), 2817-2830.

Mercante, C. T. J., Vaz-dos-Santos, A. M., Moraes, M. A. P., Pereira, J. T., \& Lombardi, J. V. (2014). Bullfrog (Lithobates catesbeianus) farming system: Water quality and environmental changes. Acta Limnologica Brasiliensia, 26, 9-17.

Olaniyi, C. O., \& Salau, B. A. (2013). The effect of pawpaw (Carica papaya) leave meal on the growth performance and blood profile of African cat fish. Transnational Journal of Science and Technology, 3(7), 1-13.

Rodriquez-Serna, M. A., Flores-Nava, M. A., Olvera-Nova, C., \& Carmona-Osalde, C. (1996). Growth and production of bullfrog Rana catesbeiana Shaw 1802 at 3 stocking densities in a vertical intensive culture system. Aquaculture Engineering, 15, 233-242.

Sipaúba-Tavares, L. H., Morais, J. C. L., \& De Stéfani, M. V. (2008). Comportamento alimentar e qualidade de áqua em tanques de criação de girinos de rã-touro Lithobates catesbeianus. Acta Scientiarum. Animal Science, 30, 95-101.

Sretarugsa, P., Luangborisut, P., Kruatrachue, M., \& Upathan, S. E. (1997). Effects of diets with various protein concentrations on growth, survival and metamorphosis of Rana tigerina and Rana catesbeiana. Journal of the Science Society of Thailand, 23, 209-224.

Tacon, A. (1990). Standard methods for the nutrition and feeding of farmed fish and shrimp. Washington: Argent Laboratories Press.

Toledo, P. H., Suazo, R., \& Viana, M. T. (2014). Formulated diets for giant Chilean frog Calyptocephalella gayi tadpoles. Ciencia e Investigación Agraria, 41(1), 13-20.

\section{Submit your manuscript to a SpringerOpen ${ }^{\circ}$ journal and benefit from:}

- Convenient online submission

- Rigorous peer review

- Open access: articles freely available online

- High visibility within the field

- Retaining the copyright to your article

Submit your next manuscript at $\boldsymbol{\nabla}$ springeropen.com 